\title{
Ceramides with Different Acyl Chain Length in the Pathogenesis of Insulin Resistance
}

\author{
Kuzmenko Dmitry Ivanovich*, Klimentyeva Tatyana Konstantinovna \\ Department of Biochemistry and Molecular Biology with a Course in Clinical Laboratory Diagnostics of the \\ Siberian State Medical University, SSMU, Russia
}

*Corresponding Author: Kuzmenko Dmitry Ivanovich, Department of Biochemistry and Molecular Biology with a Course in Clinical Laboratory Diagnostics of the Siberian State Medical University, SSMU, Russia, Email: dik51@mail.ru

\begin{abstract}
The review analyzes the literature data that forms the basis for the "ceramide-centric" view of insulin resistance pathogenesis and obesity-associated diabetes mellitus type 2. The results of lipid analysis of adipose tissue, skeletal muscles and liver in rodents with experimental obesity, as well as biopsic specimens of diabetics indicate the high pathogenicity of specific ceramide family memebers. The degree of pathogenicity is determined by the length of the acyl chain included in de novo synthesized ceramide with the involvement of one of the six ceramide synthase isoenzymes. Selective inhibition of the ceramide synthase-6 isoenzyme to reduce the tissue level of the most pathogenic C16:0-ceramide may be a promising approach for correcting insulin resistance.
\end{abstract}

Keywords: ceramide, insulin resistance, obesity, diabetes mellitus type 2

Abbreviations: aSMase - acid sphingomyelinase, BMI - body mass index, CAT-I - carnitine acyltransferase I, CerS - ceramide synthase and its six isoenzymes (CerS1-CerS6), DES - dihydroceramide 44 -desaturase, ER - endoplasmic reticulum, FADD - Fas/Apo-1-associated death domain, FAN - factor associated with neutral sphingomyelinase activation, HDL - high-density lipoproteins, IL-6 - interleukin-6, IRS - insulin receptor substrate, LPS - lipopolysaccharides, MCP-1- monocyte chemoattractant protein-1, MIP-1 macrophage inflammatory protein-1, NADPH - nicotinamide adenine dinucleotide phosphate, reduced, nSMase - neutral sphingomyelinase, PAI-1 - plasminogen activator inhibitor-1, PDK1 - 3-phosphoinositide dependent protein kinase-1, PI3K - phosphatidylinositide 3-kinase, PKB - protein kinase B, PKC $\square$ - protein kinase C zeta, PP2A - phosphoprotein phosphatase 2A, PtdIns(3,4,5)P3 - phosphatidylinositide $(3,4,5)$ trisphosphate, PtdIns(4,5)P2 - phosphatidylinositide(4,5) bisphosphate, RBP4 - retinol binding protein-4, ROS - reactive oxygen species, SAA - serum amyloid A protein, Ser - serine, SPT - serine Cpalmitoyltransferase, TAG - triacylglyceride, TGF - transforming growth factor- $\square$, Thr-threonine, TLR4 toll-like receptor 4, TNFR - tumor necrosis factor-alpha receptor, TNFa - tumor necrosis factor alpha, TRADD - TNF receptor-associated death domain, Tyr-tyrosine, VLDL - very-low-density lipoproteins.

\section{INTRODUCTION}

George Turinsky and his team were the first to demonstrate an increase in the level of ceramides in the skeletal muscles of insulinresistant rats [1]. Thanks to their discovery the role of metabolic change in sphingolipids in the pathogenesis of obesity-associated metabolic disorders and diabetes mellitus type 2 has become clear. The results of recent independent studies have shown that normal sphingolipid metabolism is one of the most important conditions for maintaining glucose homeostasis in the body [2, 3]. These findings provided the basis for a gradual transition from the traditional "glucocentric" paradigm of insulin resistance to the "ceramidcentric" view $[4,5,6,7,8]$. During de novo ceramide biosynthesis, the sphinganine acylation reaction is catalyzed by six isoenzymes of ceramide synthase (CerS), each of which exhibits specificity to a particular acyl-CoA. This reaction determines the appearance of the ceramide molecules differing from the length of the acyl chain $[9,10,11]$. It has been established that C16:0-ceramide (palmitoyl ceramide) has the most pathogenic properties, and its synthesis is catalysd by the CerS- 6 isoenzyme $[12,13,14,15]$.

\section{Leading Links in the Pathogenesis OF OBESITY-ASSOCIATED ADIPOSE TISSUE DYSFUNCTION}

Diet-induced obesity in an initially healthy person is a direct result of a positive imbalance between the amount of energy entering the body 
with food and the intensity of its expenditure [16]. In case of obesity the body mass index (BMI) exceeds $30 \mathrm{~kg} / \mathrm{m}^{2}$ [17] and its value is positively correlated with the percentage of adipose tissue in relation to body weight [18]. Not only is the mass of subcutaneous and visceral fat growing (greater and lesser omentum of the abdominal cavity, bowel mesentery) [19], but there is also ectopic fat deposition in organs that not supposed to be used for such deposition. For example, in interfibrillar spaces of skeletal muscles and myocardium, as well as in the liver. This leads to fatty degeneration of organs [20]. Ectopic fat plays a crucial role in the development of systemic insulin resistance [20]. Visceral fat is a leading and independent risk factor for type 2 diabetes, cardiovascular diseases and diabetic cardiomyopathies [21, 22]. Adipose tissue of different localization has significant metabolic features that determine a higher pathogenic potential of visceral fat as compared to subcutaneous fat $[23,24,25,26]$. The dysfunction of adipose tissue is underpinned by the following phenomena.

\subsection{Adipocyte Hypertrophy}

Hypertrophy is the leading mechanism of fat mass growth primarily, visceral fat. Due to the growth of the lipid droplet, the cell size can increase by 3-4 times [27, 28, 29]. Adipocyte hypertrophy is the leading determinant of the cardinal changes in the biochemical, endocrine and immunological activities of adipose tissue $[30,31]$. The secretion of monocyte chemo attractant protein-1 (MCP-1) $[25,26,32,33]$ is increasing in the adipocytes even in the initial phases of adipocyte hypertrophy. The protein attracts monocytes from the bloodstream into adipose tissue [34], especially into visceral fat $[35,36,37]$. The degree of macrophage infiltration is proportional to the increase in BMI, fat mass and the degree of adipocyte hypertrophy [36].

\subsection{Intensifying the Synthesis and Secretion of Proinflammatory Cytokines}

Macrophages infiltrating adipose tissue become the main source of pro-inflammatory cytokines, and primarily, tumor necrosis factor- $\square$ (TNF$\square \square$ and interleukin-6 (IL-6) $[26,38]$. The proinflammatory cytokins are involved in the induction of chronic low-intensity inflammation of adipose tissue from where they enter the bloodstram in increasd levels. At the same time, the secretion of leptin [39], resistin [40] and retinol-binding protein (RBP4) [41] increases in adipose tissue, while adiponectin secretion decreases [42]. Adipocyte hypertrophy leads to adipocyte death and macrophages group around such cells, forming crown-like structures [43]. Fatty mass growth leads to hypoxia of whole clusters of adipocytes that move away from the capillary bed [44]. The diameter of the hypertrophied adipocyte can reach 150 microns, which exceeds the distance of oxygen molecule diffusion inside the tissue. [45] In other words, increasing the distance between the adipocyte and capillary is the leading factor of the hypoxia of growing adipose tissue, which is exacerbated by its inadequate vascularization. Hypoxia is shown in the obesity model [46] and in obese patients [47]. Hypoxic microregions of adipose tissue become the sites of increased local expression of chemoattractant factors, which in its turn promotes the attraction and retention of additional macrophages into adipose tissue [48, 49].

\subsection{Chronic Inflammation}

Hypoxia stimulates the secretion of many adipokines, including pro-inflammatory cytokines, which, acting paracrinely, produce chronic inflammation [50]. Along with the above-mentioned pro-inflammatory cytokines (TNF- $\square$ and IL-6), the growing adipose tissue increases the secretion of other inflammatory mediators: interferon- $\gamma$, C-reactive protein, IL-1, IL-8, fibrinogen, haptoglobin, metallothionein, progranulin, transforming growth factor- $\square$, plasminogen activator inhibitor-1 (plasminogen activator inhibitor-1: PAI-1), serum amyloid A (SAA protein) and macrophage inflammatory protein-1 $[25,26,33,51]$. The growth of fat mass, its hypoxia and inflammation are highly integrated processes that play the primary role not only in the pathogenesis of local insulin resistance (in the adipose tissue itself), but also in systemic insulin resistance (liver, skeletal muscles and myocardium) $[16,26]$.

\subsection{Oxidative Stress}

The growth of fat mass leads to the formation of oxidative stress $[52,53,54,55,56,57,58]$. It was found that the mass of visceral fat positively correlates with the tissue content of oxidative stress markers [59]. Stress disrupting cellular redox homeostasis is one of the significant factors of pathogenesis and aggravation of obesity-associated insulin resistance in other body tissues $[60,61]$. The leading causes of oxidative stress in hypertrophied adipocytes are increased activity of NADPH oxidase, increased production of hydrogen peroxide by mitochondria respiratory chain, and weakening 
of the antioxidant defense system [62, 63, 64, 65]. Pathogenetic links of oxidative stress and inflammation in adipose tissue form a vicious cycle and mutually reinforce each other. Excessive reactive oxygen species (ROS), active forms of nitric oxide and lipid hydroperoxide together with inflammatory mediators leave the adipose tissue and enter the bloodstream, thereby participating in the formation of systemic chronic inflammation and oxidative stress in the body of an obese patient [66].

\subsection{Permanent Activation of Deposited Triacylglycerol Lipolysis}

Hydrolysis of triacylglycerol (TAG) accumulated in adipocytes is catalyzed by hormone-sensitive lipase. Insulin inhibits the lipase by suppressing its phosphorylation. In the case of obesity, the relative deficiency of insulin contributes to the stabilization of the hormonesensitive lipase in phosphorylated, that is, in the active form [67]. Another mechanism for enhancing lipolysis in adipose tissue is associated with an increase in the concentration of glucocorticoids in the blood and an increase in the expression of $\square_{1}$ and $\square_{2}$-adrenergic receptors in adipocytes $[68,69,70]$. For these reasons, one of the characteristic manifestations of abnormal fat metabolism in case of obesity is the permanent activation of lipolysis, due to which persistent hyperlipidemia is formed and large quantities of nonesterified fatty acids are delivered to skeletal muscles, the liver and the myocardium [71, 72]. Along with hyperlipidemia, dyslipidemia is produced. It is characterized by an increase in the amount of very low-density lipoproteins (VLDL), a decrease in high density lipoproteins (HDL) [73], and a substantial increase in the level of ceramides and other sphingolipids in the bloodstream [74]. This is facilitated by a significant increase in the amount of ceramides in hypertrophied adipocytes $[54,58]$. Thus, dysfunction of adipose tissue provides the tissue with a high pathogenic potential and gives reason to consider it as a primary site for localization of insulin resistance in the body, followed by the formation of systemic resistance to hormone [31].

\section{Mechanisms OF CERAMIDE ACCUMUlation IN ADIPOCYTES IN THE CASE OF OBESITY}

Each of the leading metabolic events that cause dysfunction of adipose tissue increases the amount of ceramides in adipocytes.

Ceramide accumulation within the cells ensures two main processes. One of them is an activation of de novo ceramide synthesis and enhancement of the hydrolysis of membrane sphingomyelin with the release of ceramide [6, 75]. Thus, the increase in the concentration of saturated nonesterified fatty acid and primarily palmitic acid provides an increased inflow of one of the substrates for the first rate-limiting reaction of the de novo pathway for the ceramide synthesis catalyzed by serine palmitoyltransferase (SPT) [76, 77]. In addition, palmitic acid, being one of the naturally occurring ligands of toll-like receptor 4 (TLR4) macrophages [78], is capable of stimulating de novo ceramide synthesis, presumably as a result of TLR4-mediated activation of genes encoding SPT [58]. These data confirm the involvement of long chain saturated fatty acid in the activation of macrophages of adipose tissue and are consistent with the results [79], indicating the essential role of TLR4 in the formation of obesity-associated insulin resistance in skeletal muscles and the liver. Confirmation of TLR4 involvement was obtained in studies on mutant mice with inactivated toll-receptors. It was discovered that the animals were resistant to the development of obesity while following a highcalorie diet [80].

Experiments on mice of C57BL / 6J show that administration of TNF- $\alpha$ increased both SPT activity in adipose tissue, and the activity of neutral and acidic isoforms of sphingomyelinase (nSMase and aSMase) that catalyze the hydrolysis of membrane sphingomyelin with the release of ceramide, helping to increase its intracellular concentration [54]. The effect mechanism can be explained by the fact that TNF- $\alpha$ activates the tumor necrosis factor receptor (TNFR). TNFR has two cytoplasmic domains, one of which is associated with the adapter protein factor associated with neutral sphingomyelinase activation (FAN). Due to this, there is a functional interface between TNFRTNF- $\alpha$ and nSMase associated with the plasma membrane, which ensures its activation. Another TNFR domain, the deth domain, is associated with TNF receptor-associated death domain (TRADD) pro-apoptotic adapter proteins and Fas / Apo-1-associated death domain (FADD). They provide activation of aSMase, which is translocated to the plasma membrane from the lysosome compartment [81, $82,83]$. It is also shown that incubation of adipocyte culture 3T3-L1 of mouse with ceramides and sphingosine induced gene expression induction encoding proinflammatory cytokines (PAI-1, TNF- $\alpha$, MCP-1 and IL-6). This emphasizes the role of sphingolipids in the 
pathogenesis of adipose tissue inflammation [54]. These observations are consistent with the results of studies [84], which found out that TNF- $\alpha$ and other pro-inflammatory cytokines are involved in the activation of lipolysis deposited TAG by affecting adipocytes with paracrine mechanisms.

In obese patients there is a significant decrease in the expression of the gene coding the antioxidant enzyme of adipose tissue NADPH: quinone oxidase reductase-1. It was established that there is a direct correlation between the degree of suppression of gene expression and the severity of obesity and the degree of insulin resistance [85]. This information is consistent with the data of other authors who previously demonstrated the ability of ceramides to inhibit electron transportation at levels I [86] and III [87] of the mitochondrial respiratory chain complexes, which led to a significant increase in the formation of ROS in organelles [88]. Elevated concentrations of ROS are capable of inducing reversible inhibition of carnitinacyltransferase-I (CAT-I) [89]. The decrease in the activity of CAT-I disrupts the transportation of long-chain acylcarnitins to the mitochondrial matrix, suppressing their oxidation, which, along with the permanent activation of lipolysis, promotes the growth of the concentration of long chain saturated fatty acids in the cell and increases their availability for SPT.

Ultimately, due to the increase in the concentration of saturated fatty acids, ceramides and other sphingolipids in adipocytes, they enter the bloodstream from adipose tissue and, together with pro-inflammatory cytokines, are delivered to the liver, skeletal muscles, myocardium and other organs, which triggers the formation of systemic resistance to insulin $[76,90,91,92,93]$.

4. Adipose TiSSUE AS A SOURCE OF SUBSTRATES FOR THE ACTIVATION OF SPHINGOLIPID SYNTHESIS IN THE LIVER AND SKeLETAL MUSCleS

The accumulation of ceramides and other sphingolipids in skeletal muscle, liver and myocardium cells as a result of ectopic lipid deposition in obesity plays an important role in the pathogenesis of systemic insulin resistance. This is indicated by the results of both experimental studies [1, 94, 95, 96, 97, 98], as well as data from a survey of obese patients [99, $100,101]$. Thus, it was shown that the intracellular content of ceramides and other sphingolipids in obese patients with insulin resistance is always significantly higher than normal. On average, their content in liver was higher by $26-150 \%$ and in skeletal muscles by $22-94 \%$ [6].

Only long-chain saturated fatty fcids are involved into the de novo ceramide synthesis: palmitic (C16:0), stearic (C18:0), arachidonic (C20:0) and linoceric (C24:0) fatty acids. [97, 102, 103]. This information formed the basis for the assumption that the excessive intake of saturated fatty acids in the cells, combined with the inhibition of their oxidation, can promote the activation of ceramide and other sphingolipid synthesis, as well as their accumulation in cells $[104,105]$. Evidence for this was obtained by the rodent obesity model. The model helped to establish the direct relationship between the content of ceramides in hepatocytes and the degree of manifestation of fatty liver dystrophy [106].

The possibility of a significant weakening of obesity-associated insulin resistance in rats by inhibiting the synthesis of ceramides is shown [92]. However, the administration of a balanced medication to intact mice with the myriocin, an SPT inhibitor, was conducted to suppress the de novo ceramide synthesis, to impair glucose tolerance and to form insulin resistance [3]. This indicates that a certain level of ceramide is necessary in cells for the stabilization of glucose homeostasis.

Experimental observations and results of lipid analysis of biomaterial (adipose tissue and skeletal muscle biopsy from obese patients) indicate that activation of synthesis and intracellular accumulation of nonesterified fatty acid and sphingolipids in hypertrophied adipocytes ensure their excessive intake through the bloodstream into the liver, skeletal muscles and myocardium of various lipids and substrates for the de novo ceramid synthesis. Thus, at least in the initial phase of the disease, the flow of precursors from hypertrophied adipose tissue becomes an important factor in enhancing the synthesis of ceramides and other sphingolipids in the liver and muscles by participating in ectopic accumulation of lipids.

\section{ViOLATION MECHANISMS OF INSULIN SigNALING UNDER THE INFLUENCE OF Ceramides}

The results of experiments and examinations of obese patients allow the consideration of ceramide as an intermediate, which provides a connection between all known links in the 
pathogenesis of obesity-associated insulin resistance [107].

Protein kinase $\mathrm{B}(\mathrm{PKB})$ is the central mediator of multiple anabolic insulin effects. The ability of ceramide to inhibit PKB is confirmed by the following data. It was shown that, in response to infusion of rodent emulsions of animal fat (predominantly saturated lipids) or soybean oil (predominantly unsaturated lipids), inhibition of PKB activity and inhibition of glucose uptake by muscles and adipose tissue were observed. However, the increase in ceramide tissue content occurred only with the introduction of animal fat emulsions [2, 92]. Similar results were obtained when examining obese patients with insulin resistance, which showed more than 2-fold excess of tissue content of ceramide compared to healthy individuals [99]. Infusion of the lipid emulsion to humans caused an increase in the level of ceramide in skeletal muscles, which was accompanied by a violation of their sensitivity to insulin [100]. An inverse correlation was established between intracellular ceramide content and PKB activity [108]. In the experimental obesity model, it was shown that the tissue level of ceramides was always combined with a decrease in the activity of PKB [109], while the administration of ceramide synthesis inhibitors, myriocin and cycloserine (inhibitors of SPT) or fumonisin B1, CerS inhibitor, led to the restoration of PKB activity [97]. Incubation of adipocyte culture in 3T3-L1 [110] and other cell types with palmitic acid was accompanied by ceramide accumulation and PKB inhibition. In the culture of 3T3-L1 cells, it was shown that ceramide analogues reproduced the effect of palmitic acid [111]. Cell cultures also demonstrated that inhibition of ceramide glycosylation exacerbated PKB inactivation induced by palmitic acid [112]. This effect turned out to be possible under the conditions of increased ceramidase activity, which contributed to a decrease in ceramide content [113].

It has been shown that ceramide introduced into the culture medium of hepatocytes and myocytes causes a decrease in glycogen synthesis, as well as glucose uptake in adipocytes and muscle cells, which is based on PKB inhibition activity [91, 92].

On many types of cells, including adipocytes, the mechanism of PKB inactivation by ceramide is well recorded, which is realized in two ways. First, ceramide is a direct activator of phosphoprotein phosphatase 2A (PP2A) [96, 97, 117] under the influence of which the dephosphorylation of serine-473 (Ser-473) and threonine-308 (Thr308) residues, which are necessary for the stabilization of the active kinase conformation, occurs in the PKB molecule $[96,114,115,116]$. Okadaic acid, an inhibitor of PP2A, reverses the effect of ceramide on PKB [117]. Secondly, ceramide is able to prevent the binding of PKB to the membrane complex, which includes phosphatidylinositol-3,4,5-trisphosphate (PtdIns $(3,4,5)$ P3) and 3-phosphoinositide-dependent protein kinase-1 (PDK1) [118, 119]. Ceramide acts indirectly. It activates PKC $\square$ as a result of interaction with its domain, which is rich in cysteine $\quad[120, \quad 113,121,122]$. PKC $\square$ phosphorylates the Ser and Thr residues in the $\mathrm{PH}$ domain of the $\mathrm{PKB}$, which deprives it of its ability to bind to the PtdIns $(3,4,5)$ P3PDK1 complex [120]. The experiment showed that PKC $\square$ inhibitors can improve insulin sensitivity and reverse ceramide-induced inhibition of PKB in animal tissues [120, 123]. Both mechanisms of $\mathrm{PKB}$ inactivation by a ceramide (PP2A- and $\mathrm{PKC} \square$-mediated mechanisms) operate in adipocyte (culture 3L3-L1) $[124,125]$. The reality of ceramide effects was confirmed in the paper by D.J. Powell and the coauthrs [113], whose results showed that the endogenous increase in the intracellular content of ceramide (approximately 50\% of the initial value) was sufficient for activation of PP2A and $\mathrm{PKC} \square$-mediated mechanisms of PKB inhibition.

According to the literature, it is possible that there are other mechanisms for insulin signaling violation under the action of ceramides, but not all researchers have confirmed their existence. Thus, there is evidence that ceramide is able to prevent the phosphorylation of tyrosine residues (Tyr) in the molecule of the insulin receptor substrate (IRS), which catalyzes the tyrosine protein kinase of the cytoplasmic domains of the insulin receptor [126]. A possible mechanism for the effect of ceramide is its ability to activate mixed-line kinase-3 [127], which then activates kinase of the c-Jun N-terminal kinase (JNK) [128]. JNK phosphorylates the Ser-307 residue in the IRS molecule [129, 130], counteracting this phosphorylation of Tyr residues there [131]. In favor of the reality of such a mechanism, the work [130] can be seen in which it is shown that in mice with experimental obesity JNK activity is significantly increased, and in the IRS molecule the Ser-307 residue is phosphorylated. It is also shown that in humans, a gene mutation that encodes a protein that binds JNK and causes inhibition of this kinase is accompanied 
by type 2 diabetes [132]. The result of excessive phosphorylation of the Ser residues in the IRS composition, deprives this molecule of the ability to interact further with phosphatidylinositol3-kinase (PI3K) and activate it. In turn, inhibition of PI3K activity cancels the phosphorylation of membrane phosphatidylinositol-4,5-bisphosphate (PtdIns (4,5) P2) at position 3 of its inositol ring, which excludes the formation of PtdIns $(3,4,5)$ P3. The absence of the PtdIns $(3,4,5) \mathrm{P} 3$ in the inner layer of a cell membrane deprives PDK1 of a specific binding site, which ultimately prevents the formation of the PtdIns $(3,4,5)$ P3PDK1 complex. Activation of PKB occurs only as a result of its accession to this complex. The absence of the PtdIns (3, 4, 5) P3-PDK1 complex excludes the transfer of the PKB to the active conformation.

\section{The Ceramidocentric View of the INSULIN RESISTANCE PATHOGENESIS}

This view emerged due to the great progress achieved over the past decade in studying the diversity of functions of sphingolipids and, in particular, ceramides. This was made possible by the improvement in lipidomics methods (the use of mass spectroscopy to study the qualitative composition of ceramides and other sphingolipids) and genomics (cloning of genes encoding most known enzymes of sphingolipid metabolism and obtaining lines of knockout mice according to corresponding genes) $[4,5$, $6]$. The first work that drew attention to the role of sphingolipids in the pathogenesis of metabolic dysfunction in obesity was the article by J. Turinsky and co-authors [1], which reported a substantial increase in the content of ceramide in skeletal muscle of insulin resistant rats. The chronology of the key publications that confirmed the role of ceramides and the pathogenesis of insulin resistance is given in the review [133].

Modern research approaches and model systems, including the lines of mice with knockout genes encoding the enzymes of ceramide synthesis, and the use of their specific inhibitors, allow initiation of endogenous ceramide accumulation in the cells of the tissues studied. With their help, it was proven that palmitic acid is able to increase the intracellular content of ceramide, which, unlike other sphingolipids, is responsible for inhibition of PKB [92, 94, 96, 97, 113, 120, 134]. These facts were confirmed on rodent preparations in the experiment [91], as well as on biopsy specimens of skeletal muscles and subcutaneous fat from obese patients [135].
In the mammalian body, ceramide is a family of closely related molecules numbering more than one hundred representatives, which is proved by mass spectrometric analysis [136, 137, 138]. This set of ceramides is synthesized due to the combined action of several enzymes (combinatorial biosynthesis) that determine the specificity of each structural modification of the ceramide molecule $[4,139]$. Ceramide (Nacylsfingosine) consists of sphingosine (a "structural base"), to which a variable length acyl chain is attached to the C-2 atom of which an amide bond is attached. Five positions are distinguished in the ceramide molecule, according to which its modification can occur in vivo. This explains the existence of approximately 150 individual members of the ceramide family that have been identified in human and animal tissues using massspectrometry $[4,139]$.

De novo ceramide synthesis begins with the condensation reaction of Ser and palmitoyl-CoA catalyzed by SPT. The availability of palmitic acid limits the rate of biosynthesis of ceramide. The reaction product, 3-ketosfinguanine, is reduced with the participation of 3-ketosfinguan reductase to form sphinganine. Further, the sphinganin is acylated to form $\mathrm{N}$-acylsfiganine (dihydroceramide): acyl is added to the amino group at position 2 of the sphinganin. The reaction catalyzes CerS, or sphinganin-Nacyltransferase. Finally, N-acylsfiganine (dihydroceramide), with the participation of dihydroceramide desaturase (DES), is converted to ceramide [140]. The length of the acyl chain in the individual ceramide determines its biological activity [4, 139]. Six isoforms of the CerS (CerS-1 - CerS-6), which have substrate specificity with respect to the length of the acylCoA to be joined, are identified. Obviously, specific CerS isoforms determine the appearance of ceramides with an individual acyl chain length that can contain from 14 to 30 carbon atoms $[9,10,11]$.

The introduction of lipid analysis allowed to assess the tissue balance in ceramides, which differ in length of the acyl chain. It was proved that the qualitative composition of the tissue pool of ceramides plays a decisive role, which regularly changes under obesity conditions [138]. It was found that in mice with genetic obesity (ob/ob line), compared to wild-type mice, the activity of SPT was significantly increased in adipose tissue. In the adipocytes of these animals, the content of $\mathrm{C}_{14: 0}$-ceramide was statistically significantly higher and the content 
of $\mathrm{C}_{18: 1^{-}}, \mathrm{C}_{24: 0^{-}}$and $\mathrm{C}_{24: 1^{-}}$ceramides was reduced. In the blood serum, the content of $\mathrm{C}_{16: 0^{-}}$ ceramide significantly increased in the presence of a high content of $\mathrm{C}_{18: 1^{-}}, \mathrm{C}_{24: 0^{-}}$and $\mathrm{C}_{24: 1^{-}}$ ceramides. When the culture of adipocytes was incubated in the presence of exogenous ceramide and other sphingolipids, the synthesis of TNF- $\alpha$ and other pro-inflammatory cytokines were significantly increased [54].

When examining the composition of subcutaneous fat in obese women (BMI 30-40 $\mathrm{kg} / \mathrm{m}^{2}$ ) with varying degrees of hepatic steatosis, it was found that $\mathrm{C}_{18: 0^{-}}, \mathrm{C}_{18: 1^{-}}, \mathrm{C}_{22: 0^{-}}$, and $\mathrm{C}_{24: 1^{-}}$ ceramides, and the expression of genes encoding aSMase was increased, compared to those in a subgroup of patients with a normal lipid content in the liver [141].

A significant increase in the content of ceramides was shown in abdominal subcutaneous fat in obese individuals (BMI > 30 $\mathrm{kg} / \mathrm{m}^{2}$ ): $31 \%$ in women and $34 \%$ in men compared with healthy individuals (BMI $<25$ $\mathrm{kg} / \mathrm{m}^{2}$ ). Regardless of the sex, the content of $\mathrm{C}_{14: 0^{-}}, \mathrm{C}_{16: 0^{-}}$and $\mathrm{C}_{24: 0^{-}}$ceramides was increased in adipose tissue. In addition to this, $\mathrm{C}_{18: 1^{-}}$ ceramide predominated in men, and in women $\mathrm{C}_{24: 1}$-ceramide. The activity of SPT and nSMase in subcutaneous fat was significantly higher in obese persons than in the comparison group. Reliable correlations were found between the content of total ceramide in adipose tissue and the activity of SPT $(r=0.72)$ and nSMase $(r=$ 0.59). According to the authors, the increase in the content of ceramides in subcutaneous fat is caused by an increase in the activity of SPT and nSMase [142].

The suppression of de novo ceramide synthesis with the help of myriocin preparation (specific inhibitor of SPT - rate-limiting enzyme de novo synthesis of ceramide [143]) contributed to the leveling of insulin resistance of skeletal muscle in rats with experimental (dexamethasone) diabetes, among other things by eliminating the inhibitory effect of ceramide on PKB activity. Knockout for the genes encoding the enzyme DES (homozygous null mice) was accompanied by a complete lack of its activity and an extremely low content of ceramide in the liver, muscles, myocardium, and white mice in comparison with not only wild type mice, but also heterozygous animals with DES knockout, and heterozygotes showed poor resistance to the induction of experimental diabetes. Homozygous null mice differed from heterozygotes with low survival after birth. In the rats of the Zucker line at the age of 10-11 weeks the diabetes mellitus is spontaneously formed. Course administration to rats of this line of myriocin, starting from the 8th week after birth, had a pronounced antidiabetic effect, including preventing the accumulation of ceramides in liver, muscles and blood serum. In rats of the Zucker line with already formed diabetes, the course administration of myriocin significantly increased the sensitivity of tissues to insulin. These data suggest that selective suppression of the synthesis of the most pathogenic representatives of the ceramide family can be used as a basis for new approaches to drug correction of insulin resistance in alimentary obesity $[2,133]$.

In visceral fat of overweight people, as well as in white fat and liver of mice with obesity caused by a lipid diet, similar shifts in sphingolipid metabolism were observed: increased expression of CerS-6 and increased content of $\mathrm{C}_{16: 0}$-ceramide. Experimental obesity intensified the expression of CerS-6 also in the liver. In people and mice, the increase in CerS-6 expression was positively correlated with the degree of resistance to insulin. Knockout of the gene encoding CerS-6 in mice was accompanied by a decrease in the tissue content of $\mathrm{C}_{14: 0^{-}}$and $\mathrm{C}_{\text {16:0 }}$-ceramides. Mouse mutants showed resistance to obesity induced by a lipid diet, they had difficulty developing insulin resistance. Deficiency of activity of CerS-6 promoted more active $\beta$-oxidation of fatty acids, which increased the energy expenditure of the organism of these animals [13].

It is known that the dominant isoform of ceramide synthase in the liver of mice is CerS-2, which catalyzes the synthesis of ceramides with a very long acyl chain: $\mathrm{C}_{22: 0^{-}}, \mathrm{C}_{24: 0^{-}}$and $\mathrm{C}_{24: 1^{-}}$ ceramides [11]. In this regard, the results of studies with knockout of the gene encoding CerS-2 are of interest. It was shown [12] that knockout resulted in a decrease in the liver content of $\mathrm{C}_{24: 0^{-}}$and $\mathrm{C}_{24: 1^{-}}$-ceramide mice in mice without significant effect on the content of $\mathrm{C}_{\text {16:0 }}$-ceramide. However, it was important that a diet high in lipids multiply increased the $\mathrm{C}_{16: 0^{-}}$ ceramide content in the liver of mutant mice compared to that of normal animals. This was consistent with the fact that obesity-induced diet in knockout mice significantly increased the activity of CerS-6 in the liver and decreased the activity of CerS-2 compared to their activity in normal animals [12]. These data were confirmed by the authors in separate studies on hepatocyte 
culture. It turned out that the overexpression of CerS-2 did not lead to a significant shift in the spectrum of ceramides, while overexpression of CerS-6 significantly increased the content of $\mathrm{C}_{16: 0}$-ceramides in cells, while decreasing ceramides with a very long acyl chain [12].

\section{CONCLUSION}

The physiological level of specific ceramides and other sphingolipids in cells is necessary to preserve glucose homeostasis in the body. Both quantitative and qualitative changes in the spectrum of tissue ceramides are an important factor in the pathogenesis of obesity-associated insulin resistance.

Ceramide is represented by a vast family of closely related molecules, which in particular have specificic length of the acyl chain in its molecule. CerS is one of the four enzymes of the de novo pathway for the ceramide synthesis, which is responsible for the inclusion of a strictly defined length in the molecule to be synthesized. Analysis of the clinical material and the results of model experiments showed that increased expression of the isoenzyme CerS-6 positively correlated with the degree of resistance to insulin. These patterns are confirmed by studies on the lines of mice with knockout of genes encoding CerS-6. CerS-6 shows a high specificity for palmitic acid and catalyzes the synthesis of $\mathrm{C}_{16: 0^{-}}$ ceramide (palmitoylceramide). $\mathrm{C}_{16: 0}$-ceramide has the greatest pathogenic potential: it not only suppresses the activity of $\mathrm{PKB}$, which underlies the molecular mechanism of systemic resistance to insulin, but also integrates all links of its pathogenesis with alimentary obesity.

The creation of a specific inhibitor of CerS-6 will allow selectively to reduce the tissue content of

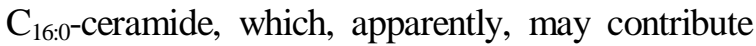
to the development of a new direction of pathogenetically grounded pharmacological correction of obesity-associated insulin resistance.

\section{REFERENCES}

[1] Turinsky, J., O’Sullivan, D.M. and Bayly, B.P. (1990) 1,2-diacylglycerol and ceramide levels in insulin-resistant tissues of the rat in vivo, $J$. Biol. Chem., 265, 16880-16885.

[2] Holland, W. L., Brozinick, J. T., Wang, L. P., Hawkins, E. D., Sargent, K.M., Liu, Y., Narra, K., Hoehn, K.L., Knotts, T.A., Siesky, A., Nelson, D.H., Karathanasis, S.K., Fontenot, G.K., Birnbaum, M.J. and Summers, S.A. (2007). Inhibition of ceramide synthesis ameliorates glucocorticoid-, saturatedfat-, and obesity-induced insulin resistance, Cell Metab., 5, 167-179.
[3] Yang, G., Badeanlou, L., Bielawski, J., Roberts, A. J., Hannun, Y. A. and Samad, F. (2009) Central role of ceramide biosynthesis in body weight regulation, energy metabolism, and the metabolic syndrome, Am. J. Physiol. Endocrinol. Metab., 297, E211-E224.

[4] Hannun, Y.A. and Obeid, L.M. (2002). The Ceramide-centric universe of lipidmediated cell regulation: stress encounters of the lipid kind, $J$. Biol. Chem., 277, 25847-25850.

[5] Savage, D.B., Petersen, K.F. and Shulman, G.L. (2005) Mechanisms of insulin resistence in humans and possible links with inflammation, Hypertension, 45, 828-833.

[6] Holland, W.L. and Summers, S.A. (2008) Sphingolipids, insulin resistance, and metabolic disease: new insights from in vivo manipulation of sphingolipid metabolism, Endocr. Rev., 29, 381-402.

[7] Kuzmenko D.I. and Klimentyeva T.K. (2016) Role of Ceramide in Apoptosis and Development of Insulin Resistance. Biochemistry (Mosc). 81, 91327.

[8] Aburasayn H., Al Batran R. and Ussher J.R. (2016) Targeting ceramide metabolism in obesity. Am J Physiol Endocrinol Metab 311: E423-E435.

[9] Levy, M., and Futerman, A.H. (2010) Mammalian ceramide snthases, IUBMB Life., 62, 347-356.

[10] Pewzner-Jung, Y., Park, H., Laviad, E. L., Silva, L. C., Lahiri, S., Stiban, J., Erez-Roman, R., BruËgger, B., Sachsenheimer, T., Wieland, F., Prieto, M., Merrill, A. H., Jr. and Futerman, A. H. (2010) A critical role for ceramide synthase 2 in liver homeostasis: I. alterations in lipid metabolic pathways, J. Biol. Chem. 285, 10902-10910.

[11] Stiban, J., Tidhar, R. and Futerman, A.H. (2010) Ceramide synthases: roles in cell physiology and signaling, Adv Exp Med Biol., 688, 60-71.

[12] Raichur, S., Wang, S. T., Chan, P.W., Li, Y., Ching, J., Chaurasia, B., Dogra, S., O* hman, M. K., Takeda, K., Sugii, S., Pewzner-Jung, Y., Futerman, A.H. and Summers, S.A. (2014) CerS2 haploinsufficiency inhibits b-oxidation and confers susceptibility to diet-induced steatohepatitis and insulin resistance, Cell Metab., 20, 687-695.

[13] Turpin, S.M., Nicholls, H.T., Willmes, D.M., Mourier, A., Brodesser, S., Wunderlich, C. M., Mauer, J., Xu, E., Hammerschmidt, P., Bronneke, H. S., Trifunovic, A., LoSasso, G., Wunderlich, F. T., Kornfeld, J.-W., Bluher, M., Kronke, M. and Bruning, J. C. (2014) Obesity-induced CerS6dependent C16:0 ceramide production promotes weight gain and glucose intolerance, Cell Metab., 20, 678-686.

[14] Reali F, Morine M.J., Kahramanoğulları O., Raichur S., Schneider H.-Ch., Crowther D. and Priami C. (2017) Mechanistic interplay between ceramide and insulin resistance. Scientific Reports, 7, 41231 
[15] Fucho R., Casals N., Serra D. and Herrero L. (2017) Ceramides and mitochondrial fatty acid oxidation in obesity. FASEB J. 31, 1263-1272.

[16] Bluher, M. (2009) Adipose tissue dysfunction in obesity, Exp. Clin. Endocrinol. Diabetes, 117, $241-250$.

[17] Barness, L.A., Opitz, J.M. and Gilbert-Barness, E. (2007) Obesity: genetic, molecular, and environmental aspects, Amer. J. Med. Gene., 143A, 3016-3034.

[18] Romero-Corral, A., Somers, V.K., Sierra-Johnson, J., Thomas, R.J., Collazo-Clavel,l M.L., Korinek, J., Allison, T.G., Batsis, J.A., Sert-Kuniyoshi, F.H. and Lopez-Jimenez, F. (2008) Accuracy of body mass index in diagnosing obesity in the adult general population, Int. J. Obesity, 32, 959-966.

[19] Reaven, G.M. (1988) Banting lecture 1988. Role of insulin resistance in human disease, Diabetes, 37, 1595-1607.

[20] Rasouli., N., Molavi, B., Elbein, S.C. and Kern, P.A. (2007) Ectopic fat accumulation and metabolic syndrome, Diabetes Obes. Metab., 9, 110.

[21] Yusuf, S., Hawken, S., Ounpuu, S., Bautista, L., Franzosi, M.G., Commerford, P., Lang, C.C., Rumboldt, Z., Onen, C.L, Lisheng, L., Tanomsup, S., Wangai, P. Jr., Razak, F., Sharma, A.M. and Anand, S.S. (2005) INTERHEART Study Investigators. Obesity and the risk of myocardial infarction in 27000 participants from 52 countries: a case-control study, Lancet, 366, 1640-1649.

[22] Amaral, N. and Okonko, D.O. (2015) Metabolic abnormalities of the heart in type II diabetes, Diab. Vasc. Dis. Res., 12, 239-248.

[23] Berndt, J., Kralisch, S., Kloting, N., Ruschke, K., Kern, M., Fasshauer, M., Schön, M.R., Stumvoll, M. and Blüher, M. (2008) Adipose triglyceride lipase gene expression in human visceral obesity, Exp. Clin. Endocrinol. Diabetes., 116, 203-210.

[24] Van Harmelen, V., Rohrig, K. and Hauner, H. (2004) Comparison of proliferation and differentiation capacity of human adipocyte precursor cells from the omental and subcutaneous adipose tissue depot of obese subjects, Metabolism, 53, 632-637.

[25] Bluher, M., Fasshauer, M., Tonjes, A., Kratzsch, J., Schön, M.R. and Paschke, R. (2005) Association of interleukin-6, C-reactive protein, interleukin-10 and adiponectin plasma concentrations with measures of obesity, insulin sensitivity and glucose metabolism, Exp. Clin. Endocrinol. Diabetes, 113, 534-537.

[26] Bluher, M. (2008) The inflammatory process of adipose tissue, Pediatr. Endocrinol. Rev., 6, 2431.

[27] Spalding, K.L., Arner, E., Westermark, P.O., Bernard, S., Buchholz, B.A., Bergmann, O., Blomqvist, L., Hoffstedt, J., Näslund, E., Britton, T., Concha, H., Hassan, M., Rydén,
M., Frisén, J. and Arner, P. (2008) Dynamics of fat cell turnover in humans, Nature, 453, 783787.

[28] Tchoukalova, Y.D., Koutsari, C., Votruba, S.B., Tchkonia, T., Giorgadze, N., Thomou, T., Kirkland, J.L. and Jensen, M.D. (2010) Sexand depot-dependent differences in adipogenesis in normal weight humans, Obesity (Silver Spring), 18, 1875-1880.

[29] Tchoukalova, Y.D., Votruba, S.B., Tchkoniac, T., Giorgadze, N., Kirkland, J.L. and Jensen, M.D. (2010) Regional differences in cellular mechanisms of adipose tissue gain with overfeeding, Proc. Natl. Acad. Sci. USA, 107, 18226-18231.

[30] Bays, H. and Ballantyne, C. (2006) Adiposopaty: why do adiposity and obesity cause metabolic disease? Future Lipidol., 1, 389-420.

[31] Bays, H., Gonzales-Campoy, Bray G.A., Kitabchi, A.E., Bergman, D.A, Rodbard, H.W. and Henry, R.R. (2008) Pathogenic potential of adipose tissue and metabolic consequence of adipocyte hypertrophy and increased visceral adiposity, Expert Rev. Cardiovasc. Ther., 6, 343-368.

[32] Boschmann, M., Engeli, S., Adams, F., Gorzelniak, K., Franke, G., Klaua, S., Kreuzberg, U., Luedtke, S., Kettritz, R., Sharma, A.M., Luft, F.C. and Jordan, J. (2005) Adipose tissue metabolism and CD11b expression on monocytes in obese hypertensives, Hypertension, 46, 130-136.

[33] Guilherme, A., Virbasius, J.V., Puri. V. and Czech. M.P. (2008) Adipocyte dysfunctions linking obesity to insulin resistance and type 2 diabetes, Nat. Rev. Mol. Cell. Biol., 9, 367-377.

[34] Curat, C.A., Miranville, A., Sengenes, C., Diehl, M., Tonus, C., Busse, R. and Bouloumié, A. (2004) From blood monocytes to adipose tissue-resident macrophages: induction of diapedesis by human mature adipocytes, Diabetes, 53, 1285-1292.

[35] Curat, C.A., Wegner, V., Sengenes, C., Miranville, A, Tonus, C, Busse, R, Bouloumié, A. (2006) Macrophages in human visceral adipose tissue: increased accumulation in obesity and a source of resistin and visfatin, Diabetologia, 49, 744-747.

[36] Harman-Boehm, I., Bluher, M., Redel, H., Sion-Vardy, N., Ovadia, S., Avinoach, E, Shai, I., Klöting, N., Stumvoll, M., Bashan, N. and Rudich, A. (2007) Macrophage infiltration into omental versus subcutaneous fat across diff erent populations: effect of regional adiposity and the comorbidities of obesity, J. Clin. Endocrinol. Metab., 92, 2240-2247.

[37] Lumeng, C.N., del Proposto, J.B., Westcott, D.J. and Saltiel, A.R. (2008) Phenotypic switching of adipose tissue macrophages with 
obesity is generated by spatiotemporal differences in macrophage subtypes, Diabetes, 57, 3239-3246.

[38] Skurk, T., Alberti-Huber, C., Herder, C. and Hauner, H. (2007) Relationship between adipocyte size and adipokine expression and secretion, Clin. Endocrinol. Metab., 92, 1023-1033.

[39] Considine, R.V., Sinha, M.K., Heiman, M.L., Kríauciunas, A., Stephens, T.W., Nyce, M.R., Ohannesian, J.P., Marco, C.C., McKee, L.J., Bauer, T.L. and Caro, J.F. (1996) Serum immunoreactiveleptin concentrations in normal-weight and obese humans, N. Engl. j Med., 334, 292-295.

[40] Sentinelli, F., Romeo, S., Arca, M., Filippi, E., Leonetti, F., Banchieri, M., Di Mario, U. and Baroni, M.G. (2002) Human resistin gene, obesity and type 2 diabetes: mutation analysis and population study, Diabetes, 51, P. 860-862.

[41] Graham, T.E., Yang, Q., Bluher, M., Hammarstedt, A., Ciaraldi, T.P., Henry, R.R., Wason, C.J., Oberbach, A., Jansson, P.A., Smith, U. and Kahn, B.B. (2006) Retinol-binding protein 4 and insulin resistance in lean, obese, and diabetic subject, $N$. Engl. J. Med., 354, 2552-2563.

[42] Matsuzawa, Y. (2010) Adiponectin: a key player in obesity related disorders, Curr. Pharm. Des., 16, 1896-1901.

[43] Cinti, S., Mitchell, G., Barbatelli, G., Murano, I., Ceresi, E., Faloia, E., Wang, S., Fortier, M., Greenberg, A.S. and Obin, M.S. (2005) Adipocyte death defines macrophage localization and function in adipose tissue of obese mice and humans, J. Lipid Res., 46, 2347-2355.

[44] Thrush, A.B., Harasim, E., Chabowski, A., Gulli, R., Stefanyk, L. and Dyck, D.J. (2011). A single prior bout of exercise protects against palmitate-induced insulin resistance despite an increase in total ceramide content, Am. J. Physiol. Regul. Integr. Comp. Physiol., 300, R1200-R1208.

[45] Lolmède, K., Durand de Saint Front, V., Galitzky, J., Lafontan, M. and Bouloumié, A. (2003) Effects of hypoxia on the expression of proangiogenic factors in differentiated 3T3F442A adipocytes, Int. J. Obes. Relat. Metab. Disord., 27, 1187-1195.

[46] Rausch, M.E., Weisberg, S., Vardhana, P. and Tortoriello, D.V. (2008) Obesity in C57BL/6J mice is characterized by adipose tissue hypoxia and cytotoxic T-cell infiltration, Int. J. Obes (Lond)., 32, 451-463.

[47] Fleischmann, E., Kurz, A., Niedermayr, M., Schebesta, K., Kimberger, O., Sessler, D.I., Kabon, B. and Prager, G. (2005) Tissue oxygenation in obese and non-obese patients during laparoscopy, Obes. Surg., 15, 813-819.

[48] Cancello, R. and Clement, K. (2006) Is obesity an inflammatory illness? Role of low-grade inflammation and macrophage infiltration in human white adipose tissue, BJOG, 113, 11411147.

[49] Cancello, R., Henegar, C., Viguerie, N., Taleb, S., Poitou, C., Rouault, C., Coupaye, M., Pelloux, V., Hugol, D., Bouillot, J.L., Bouloumié, A., Barbatelli, G., Cinti, S., Svensson, P.A., Barsh, G.S., Zucker, J.D., Basdevant, A., Langin, D. and Clément, K. (2005) Reduction of macrophage infi ltration and chemoattractant gene expression changes in white adipose tissue of morbidly obese subjects after surgery-induced weight loss, Diabetes, 54, 2277-2286.

[50] Trayhurn, P., Wang, B. and Wood, I.S. (2008) Hypoxia in adipose tissue: a basis for the dysregulation of tissue function in obesity? $\mathrm{Br}$. J. Nutr., 100, 227-235.

[51] Youn, B.S., Kloting, N., Kratzsch, J., Lee, N., Park, J.W., Song, E.S., Ruschke, K., Oberbach, A., Fasshauer, M., Stumvoll, M. and Blüher, M. (2008) Serum vaspin concentrations in human obesity and type 2 diabetes, Diabetes, 57, 372-377.

[52] Rudich, A., Kanety, H. and Bashan, N. (2007) Adipose stress-sensing kinases: linking obesity to malfunction, Trends Endocrinol. Metab., 18, $291-299$.

[53] Jung, S.H., Park, H.S., Kim, K.S., Choi, W.H., Ahn, C.W., Kim, B.T., Kim, S.M., Lee, S.Y., Ahn, S.M., Kim, Y.K., Kim, H.J., Kim, D.J. and Lee, K.W. (2008). Effect of weight loss on some serum cytokines in human obesity: increase in IL-10 after weight loss, J. Nutr. Biochem., 19, 371-375.

[54] Samad, F., Hester, K.D., Yang, G., Hannun, Y.A. and Bielawski, J. (2006). Altered adipose and plasma sphingolipid metabolism in obesity: a potential mechanism for cardiovascular and metabolic risk, Diabetes, 55, 2579-2587.

[55] Grimsrud, P.A., Picklo, M.J.Sr., Griffin, T.J. and Bernlohr, D.A. (2007) Carbonylation of adipose proteins in obesity and insulin resistance: identification of adipocyte fatty acid-binding protein as a cellular target of 4hydroxynonenal, Mol Cell Proteomics., 4, 624637.

[56] Henriksen, E.J., Diamond-Stanic, M.K. and Marchionne, E.M. (2011) Oxidative stress and the etiology of insulin resistance and type 2 diabetes, Free Radic. Biol. Med., 51, 993-999.

[57] Murdolo, G., Piroddi, M., Luchetti, F., Tortoioli, C., Canonico, B., Zerbinati, C., Galli, F., and Iuliano, L. (2013) Oxidative stress and lipid peroxidation by-products at the crossroad between adipose organ dysregulation and obesity-linked insulin resistance, Biochimie, 95, 585-94.

[58] Schilling, J.D., Machkovech, H.M., He, L., Sidhu, R., Fujiwara, H., Weber, K., Ory D.S. and Schaffer, J.E. (2013). Palmitate and lipopolysaccharide trigger synergistic ceramide 
production in primary macrophages, J. Biol. Chem., 288, 2923-2932.

[59] Pou, K.M., Massaro, J.M., Hoffmann, U., Vasan, R.S., Maurovich-Horvat, P., Larson, M.G., Keaney, J.F. Jr, Meigs, J.B., Lipinska, I., Kathiresan, S., Murabito, J.M., O'Donnell, C.J., Benjamin, E.J. and Fox, C.S. (2007) Visceral and subcutaneous adipose tissue volumes are cross-sectionally related to markers of inflammation and oxidative stress: the Framingham Heart Study, Circulation, 116, 1234-1241.

[60] Furukawa, S., Fujita, T., Shimabukuro, M., Iwaki, M., Yamada, Y., Nakajima, Y., Nakayama, O., Makishima, M., Matsuda, M. and Shimomura I. (2004) Increased oxidative stress in obesity and its impact on metabolic syndrome, J. Clin. Invest., 114, 1752-1761.

[61] Rains, J.L. and Jain, S.K. (2011) Oxidative stress, insulin signaling, and diabetes, Free Radic. Biol. Med., 50, 567-575.

[62] Patel, C., Ghanim, H., Ravishankar, S., Sia, C.L., Viswanathan, P., Mohanty, P. and Dandona, P. (2007) Prolonged reactive oxygen species generation and nuclear factor-kappaB activation after a high-fat, high-carbohydrate meal in the obese, J. Clin. Endocrinol. Metab., 92, 4476-4479.

[63] Chrysohoou, C., Panagiotakos, D.B., Pitsavos, C., Skoumas, I., Papademetriou, L., Economou, M. and Stefanadis, C. (2007) The implication of obesity on total antioxidant capacity in apparently healthy men and women: The ATTICA study, Nutr. Metab. Cardiovasc. Dis., 17, 590-597.

[64] Anderson, E.J., Yamazaki, H. and Neufer, P.D. (2007) Induction of endogenous uncoupling protein 3 suppresses mitochondrial oxidant emission during fatty acid-supported respiration, J. Biol. Chem., 282, 31257-31266.

[65] Mlinar, B. and Marc, J. (2011) New insights into adipose tissue dysfunction in insulin resistance, Clin. Chem. Lab. Med., 49, 1925-1935.

[66] Yu, Y.H. and Ginsberg, H.N. (2005) Adipocyte signaling and lipid homeostasis: sequelae of insulin-resistant adipose tissue, Circ. Res, 96, 1042-1052.

[67] Anthonsen, M.W., Ronnstrand, L., Wernstedt, C., Degerman, E. and Holm, C. (1998) Identification of novel phosphorylation sites in hormone-sensitive lipase that are phosphorlated in response to isoproterenol and govern activation properties in vitro, J. Biol. Chem., 273, 215-221.

[68] Rebuffé-Scrive, M., Bronnegard, M., Nilsson, A., Eldh, J., Gustafsson, J.A. and Björntorp, P. (1990) Steroid hormone receptors in human adipose tissues, J. Clin. Endocrinol. Metab., 71, 1215-1219.

[69] Arner, P., Hellstrom, L. and Wahrenberg, H. (1990) Beta-adrenoceptor expression in human fat cells from different regions, J. Clin. Invest., $86,1595-1600$.
[70] Fried, S.K., Russell, C.D., Grauso, N.L. and Brolin, R.E. (1993) Lipoprotein lipase regulation by insulin and glucocorticoid in subcutaneous and omental adipose tissues of obese women and men, J. Clin. Invest., 92, 2191-2198.

[71] Coppack, S.W., Evans, R.D., Fisher, R.M., Frayn, K.N., Gibbons, G.F., Humphreys, S.M., Kirk, M.L., Potts, J.L. and Hockaday, T.D. (1992) Adipose tissue metabolism in obesity: lipase action in vivo before and after a mixed meal, Metabolism, 41, 264-272.

[72] Frayn, K.N. (2002) Adipose tissue as a buffer for daily lipid flux, Diabetologia, 45, 1201-1210.

[73] Yu, Y.H. and Ginsberg, H.N. (2005) Adipocyte signaling and lipid homeostasis: sequelae of insulin-resistant adipose tissue, Circ. Res, 96, 1042-1052.

[74] Lightle, S., Tosheva, R., Lee, A., Queen-Baker, J., Boyanovsky, B., Shedlofsky, S. and Nikolova-Karakashian, M. (2003) Elevation of ceramide in serum lipoproteins during acute phase response in humans and mice: role of serine-palmitoyl transferase, Arch. Biochem. Biophys., 419, 120-128.

[75] Summers, S.A. (2006) Ceramides in insulin resistance and lipotoxicity, Prog Lipid Res., 45, 42-72.

[76] Futerman, A. H. and Hannun, Y. A. (2004). The complex life of simple sphingolipids, EMBO Rep., 5, 777-782.

[77] Bartke, N. Hannun, Y. A. (2009) Bioactive sphingolipids: metabolism and function, $J$. Lipid Res., 50 (Suppl), S91-S96.

[78] Lee, J.Y., Plakidas, A., Lee, W.H., Heikkinen, A., Chanmugam, P., Bray, G. and Hwang, D.H. (2003) Differential modulation of Toll-like receptors by fatty acids: preferential inhibition by n-3 polyunsaturated fatty acids, J Lipid Res., 44, 479-486.

[79] Shi, H., Kokoeva, M.V., Inouye, K., Tzameli, I., Yin, H. and Flier, J.S. (2006) TLR4 links innate immunity and fatty acid-induced insulin resistance, J Clin Invest., 116, 3015-3025.

[80] Tsukumo, D.M., Carvalho-Filho, M.A., Carvalheira, J.B., Prada, P.O., Hirabara, S.M., Schenka, A.A., Araújo, E.P., Vassallo, J., Curi, R., Velloso, L.A. and Saad, M.J. (2007) Lossof-function mutation in Toll-like receptor 4 prevents diet-induced obesity and insulin resistance, Diabetes, 56, 1986-1998.

[81] Adam-Klages, S., Adam, D., Wiegmann, K., Struve, S., Kolanus, W., Schneider-Mergener, J. and Krönke, M. (1996) FAN, a novel WDrepeat protein, couples the p55 TNF-receptor to neutral sphingomyelinase, Cell, 86, 937-947.

[82] Ohanian, J. and Ohanian, V. (2001) Sphingolipids in mammalian cell signaling, Cell. Mol. Life Sci., 58, 2053-2068. 
[83] Grassme, H., Jekle, A., Riehle, A., Schwartz, H., Berger, J., Sandho, K., Kolesnick, R. and Gulbins, E. (2001) CD95 signaling via ceramide-rich membrane rafts, J. Biol. Chem., 276, 20589-20596.

[84] Nguyen, M.T., Satoh, H., Favelyukis, S., Babendure, J.L., Imamura, T., Sbodio, J.I., Zalevsky, J., Dahiyat, B.I., Chi, N.W. and Olefsky, J.M. (2005) JNK and TNF-a mediated free fatty acid-induced insulin resistance in 3T3-1 1 adipocytes, J. Biol. Chem., 280, 3536135371.

[85] Palming, J., Sjöholm, K., Jernås, M., Lystig, T.C., Gummesson, A., Romeo, S., Lönn, L., Lönn, M., Carlsson, B. and Carlsson, L.M. (2007) The expression of $\mathrm{NAD}(\mathrm{P}) \mathrm{H}$ :quinone oxidoreductase 1 is high in human adipose tissue, reduced by weight loss, and correlates with adiposity, insulin sensitivity, and markers of liver dysfunction, J. Clin. Endocrinol. Metab., 92, 2346-2352.

[86] Di Paola, M., Cocco, T. and Lorusso M. (2000) Ceramide interaction with the respiratory chain of heart mitochondria, Biochemistry, 39, 6660-6668.

[87] Gudz, T.I., Tserng, K.Y. and Hoppel, C.L. (1997) Direct inhibition of mitochondrial respiratory chain complex III by cell-permeable ceramide, J. Biol. Chem., 272, 24154-24158.

[88] García-Ruiz, C., Colell, A., Marí, M., Morales, A. and Fernández-Checa, J.C. (1997) Direct effect of ceramide on the mitochondrial electron transport chain leads to generation of reactive oxygen species: role of mitochondrial glutathione, J. Biol. Chem., 272, 11369-11377.

[89] Setoyama, D., Fujimura, Y. and Miura, D. (2013) Metabolomics reveals that carnitine palmitoyltransferase- 1 is a novel target for oxidative inactivation in human cells, Genes Cells, 18, 1107-1119.

[90] Reyna, S.M., Ghosh, S., Tantiwong, P., Meka, C.S., Eagan, P., Jenkinson, C.P., Cersosimo, E., Defronzo, R.A., Coletta, D.K., Sriwijitkamol, A. and Musi, N. (2008) Elevated tolllike receptor 4 expression and signaling in muscle from insulinresistant subjects. 57, 2595-602.

[91] Holland, W.L., Knotts, T.A., Chavez, J.A., Wang, L.P., Hoehn, K.L. and Summers, S.A. (2007) Lipid mediators of insulin resistance, Nutr. Rev., 65, S39-S46.

[92] Holland, W.L., Bikman, B.T., Wang, L.P., Yuguang, G., Sargent, K.M., Bulchand, S., Knotts, T.A., Shui, G., Clegg, D.J., Wenk, M.R., Pagliassotti, M.J., Scherer, P.E. and Summers, S.A. (2011) Lipidinduced insulin resistance mediated by the proinflammatory receptor TLR4 requires saturated fatty acid induced ceramide biosynthesis in mice, J. Clin. Invest., 121, 1858-1870.

[93] Hoehn, K.L., Hohnen-Behrens, C., Cederberg, A., Wu, L.E., Turner, N., Yuasa, T., Ebina, Y. and James, D.E. (2008) IRS1-independent defects define major nodes of insulin resistance, Cell Metab., 7, 421-433.

[94] Schmitz-Peiffer, C., Craig, D.L. and Biden, T.J. (1999) Ceramide generation is sufficient to account for the inhibition of the insulinstimulated $\mathrm{PKB}$ pathway in $\mathrm{C} 2 \mathrm{C} 12$ skeletal muscle cells pretreated with palmitate, J. Biol. Chem., 274, 24202-24210.

[95] Gorski, J., Dobrzyn, A. and ZendzianPiotrowska, M. (2002) The sphingomyelinsignaling pathway in skeletal muscles and its role in regulation of glucose uptake, Ann. N.Y. Acad. Sci., 967, 236-248.

[96] Chavez, J.A., Knotts, T.A., Wang, L.P., Li, G., Dobrowsky, R.T., Florant, G.L. and Summers, S.A. (2003) A role for ceramide, but not diacylglycerol, in the antagonism of insulin signal transduction by saturated fatty acids, $J$. Biol. Chem., 13, 10297-10303.

[97] Chavez, J.A. and Summers, S.A. (2003) Characterizing the effects of saturated fatty acids on insulin signaling and ceramide and diacylglycerol accumulation in 3T3-1 1 adipocytes and $\mathrm{C} 2 \mathrm{C} 12$ myotubes, Arch. Biochem. Biophys., 419, 101-109.

[98] Gorska, M., Dobrzyn, A., Zendzian-Piotrowska, M. and Górski, J. (2004) Effect of streptozotocindiabetes on the functioning of the sphingomyelinsignalling pathway in skeletal muscles of the rat, Horm. Metab. Res., 36, 14-21.

[99] Adams, J.M., Pratipanawatr, T., Berria, R., Wang, E., DeFronzo, R.A., Sullards, M.C. and Mandarino, L.J. (2004) Ceramide content is increased in skeletal muscle from obese insulinresistant humans, Diabetes, 53, 25-31.

[100] Straczkowski, M., Kowalska, I., Nikolajuk, A., Dzienis-Straczkowska, S., Kinalska, I., Baranowski, M., Zendzian-Piotrowska, M., Brzezinska, Z. and Gorski, J. (2004) Relationship between insulin sensitivity and sphingomyelin signaling pathway in human skeletal muscle, Diabetes, 53, 1215-1221.

[101] Gorska, M., Dobrzyn, A., and Baranowski, M. (2005) Concentrations of sphingosine and sphinganine in plasma of patients with type 2 diabetes, Med. Sci. Monit., 11, CR35-CR38.

[102] Merrill, A.H., Jr. (2002) De novo sphingolipid biosynthesis: a necessary, but dangerous, pathway, J. Biol. Chem., 277, 25843-25846.

[103] Kuller, L.H. (2006) Nutrition, lipids, and cardiovascular disease, Nutr. Rev., 64, 15-26.

[104] Unger, R.H. (2003) Lipid overload and overflow: metabolic trauma and the metabolic syndrome, Trends Endocrinol. Metab., 14, 398-403.

[105] Lelliott, C. and Vidal-Puig, A.J. (2004) Lipotoxicity, an imbalance between lipogenesis de novo and fatty acid oxidation, Int. J. Obes. Relat. Metab. Disord., 28, Suppl 4, S22-S28. 
[106] Yetukuri, L., Katajamaa, M., Medina-Gomez, G., Seppanen-Laakso, T., Vidal-Puig, A. and Oresic, M. (2007) Bioinformatics strategies for lipidomics analysis: characterization of obesity related hepatic steatosis, BMC Syst. Biol., 15, 1-12.

[107] Summers, S.A. and Nelson, D.H. (2005) A role for sphingolipids in producing the common features of type 2 diabetes, metabolic syndrome $X$, and Cushing's syndrome, Diabetes, 54,591-602.

[108] Langeveld, M. and Aerts, J.M. (2009) Glycosphin golipids and insulin resistance, Prog. Lipid. Res., 48, 196-205.

[109] Bachmann, O.P, Dahl, D.B., Brechtel, K., Machann, J., Haap, M., Maier, T., Loviscach, M., Stumvoll, M., Claussen, C.D., Schick, F., Haring, H.U. and Jacob, S. Effects of intravenous and dietary lipid challenge on intramyocellular lipid content and the relation with insulin sensitivity in humans, (2001) Diabetes, 50, 2579-2584.

[110] Van Epps-Fung, M., Williford, J., Wells, A. and Hardy, R.W. (1997) Fatty acid-induced insulin resistance in adipocytes, Endocrinology, 138, 4338-4345.

[111] Mei, J., Wang, C.N., O’Brien, L. and Brindley, D.N. (2003) Cell-permeable ceramides increase basal glucose incorporation into triacylglycerols but decrease the stimulation by insulin in 3T3-L1 adipocytes, Int J Obes Relat Metab Disord., 27, 31-39.

[112] Chavez, J.A., Holland, W.L., Bar, J., Sandhoff, K. and Summers, S.A. Acid ceramidase over expression prevents the inhibitory effects of saturated fatty acids on insulin signaling, (2005) J. Biol. Chem., 280, 20148-20153.

[113] Powell, D.J., Turban, S., Gray, A., Hajduch, E. and Hundal, H.S. (2004) Intracellular ceramide synthesis and protein kinase $\mathrm{C}$ zeta activation play an essential role in palmitate-induced insulin resistance in rat L6 skeletal muscle cells, Biochem. J., 382, 619-629.

[114] Salinas, M., Lopez-Valdaliso, R., Martin, D., Alvarez, A. and Cuadrado, A. (2000) Inhibition of $\mathrm{PKB} / \mathrm{Akt} 1$ by $\mathrm{C} 2$-ceramide involves activation of ceramide-activated protein phosphatase in $\mathrm{PC} 12$ cells, Mol. Cell. Neurosci., 15, 156-169.

[115] Schubert, K.M., Scheid, M.P. and Duronio, V. (2000) Ceramide inhibits protein kinase B/Akt by promoting dephosphorylation of serine $473, J$. Biol. Chem., 275, 13330-13335.

[116] Zinda, M.J., Vlahos, C.J. and Lai, M.T. (2001) Ceramide induces the dephosphorylation and inhibition of constitutively activated Akt in PTEN egative U87MG cells, Biochem. Biophys. Res. Commun., 280, 1107-1115.

[117] Teruel, T., Hernandez, R. and Lorenzo, M. (2001) Ceramide mediates insulin resistance by tumor necrosis factor-alpha in brown adipocytes by maintaining Akt in an inactive dephosphorylated state, Diabetes, 50, 2563-2571.
[118] Hajduch, E., Balendran, A., Batty, I.H., Litherland, G.J., Blair, A.S., Downes, C.P. and Hundal, H.S. (2001) Ceramide impairs the insulindependent membrane recruitment of protein kinase B leading to a loss in downstream signalling in L6 skeletal muscle cells, Diabetologia, 44, 173-183.

[119] Stratford, S., DeWald, D.B. and Summers, S.A. (2001) Ceramide dissociates 3'- phosphoinositide production from pleckstrin homology domain translocation, Biochem. J., 354, 359-368.

[120] Powell, D.J., Hajduch, E., Kular, G. and Hundal, H.S. (2003) Ceramide disables 3-phosphoinositide binding to the pleckstrin homology domain of protein kinase B (PKB)/Akt by a PKCzetadependent mechanism, Mol. Cell. Biol., 23, 77947808 .

[121] Bourbon, N.A., Yun, J. and Kester, M. (2000) Ceramide directly activates protein kinase $\mathrm{C}$ to regulate a stress-activated protein kinase signaling complex, J. Biol. Chem., 275, 35617-35623.

[122] Bourbon, N.A., Sandirasegarane, L. and Kester, M. (2002) Ceramide-induced inhibition of Akt is mediated through protein kinase Czeta: implications for growth arrest, J. Biol. Chem., 277, 3286-3292.

[123] Hajduch, E., Turban, S., Le Liepvre, X., Le Lay, S., Lipina, C., Dimopoulos, N., Dugail, I. and Hundal, H.S. (2008) Targeting of PKCzeta and $\mathrm{PKB}$ to caveolin-enriched microdomains represents a crucial step underpinning the disruption in PKB-directed signalling by ceramide, Biochem. J., 410, 369-379.

[124] Stratford, S., Hoehn, K.L., Liu, F. and Summers, S.A. (2004) Regulation of insulin action by ceramide: dual mechanisms linking ceramide accumulation to the inhibition of Akt/protein kinase B, J. Biol. Chem., 279, 3660836615. subjects. Diabetes 57, 2595-2602.

[125] Dey, D., Basu, D., Roy, S.S., Bandyopadhyay, A. and Bhattacharya, S. (2006) Involvement of novel PKC isoforms in FFA induced defects in insulin signaling, Mol. Cell. Endocrinol., 246, 60-64.

[126] Paz, K., Hemi, R., LeRoith, D., Karasik, A., Elhanany, E., Kanety, H. and Zick, Y. (1997) A molecular basis for insulin resistance. Elevated serine/threonine phosphorylation of IRS-1 and IRS-2 inhibitstheir binding to the juxtamembrane region of the insulin receptor and impairs their ability to undergo insulin-induced tyrosine phosphorylation, J. Biol. Chem., 272, 2991129918.

[127] Sathyanarayana, P., Barthwal, M.K., Kundu, C.N., Lane, M.E., Bergmann, A., Tzivion, G. and Rana, A. (2002) Activation of the Drosophila MLK by ceramide reveals TNFalpha and ceramide as agonists of mammalian MLK3, Mol. Cell, 10, 1527-1533.

[128] Xu, Z., Maroney, A.C., Dobrzanski, P., Kukekov, N.V. and Greene, L.A. (2001) The MLK family 
mediates c-Jun N-terminal kinase activation in neuronal apoptosis, Mol. Cell. Biol., 21, 47134724.

[129] Aguirre, V., Uchida,T.,Yenush, L., Davis, R. and White, M.F. (2000) The c-Jun NH(2)-terminal kinase promotes insulin resistance during association with insulin receptor substrate-1 and phosphorylation of Ser (307), J. Biol. Chem., 275, 9047-9054.

[130] Hirosumi, J., Tuncman, G., Chang, L., Gorgun, C.Z., Uysal, K.T., Maeda, K., Karin, M. and Hotamisligil, G.S. (2002) A central role for JNK in obesity and insulin resistance, Nature, 420, 333-336.

[131] Gual, P., Le Marchand-Brustel, Y. and Tanti, J.F. (2005) Positive and negative regulation of insulin signaling through IRS-1 phosphorylation, Biochimie, 87, 99-109.

[132] Waeber, G., Delplanque, J., Bonny, C., Mooser, V., Steinmann, M., Widmann, C., Maillard, A., Miklossy, J., Dina, C., Hani, E.H., Vionnet, N., Nicod, P., Boutin, P. and Froguel, P. (2000) The gene MAPK8IP1, encoding islet-brain-1, is a candidate for type 2 diabetes, Nat. Genet., 24, 291295.

[133] Chavez, J.A. and Summers, S.A. (2012) A Ceramide-Centric View of Insulin Resistance, Cell. Metabolism, 15, 585-594.

[134] Watson, M.L., Coghlan, M. and Hundal, H.S. (2009). Modulating serine palmitoyl transferase (SPT) expression and activity unveils a crucial role in lipid-induced insulin resistance in rat skeletal muscle cells, Biochem. J., 417, 791-801.

[135] Thrush, A.B., Harasim, E., Chabowski, A., Gulli, R., Stefanyk, L. and Dyck, D.J. (2011). A single prior bout of exercise protects against palmitate-induced insulin resistance despite an increase in total ceramide content, Am. J. Physiol. Regul. Integr. Comp. Physiol., 300, R1200-R1208.

[136] Merrill, A.H., Jr., Stokes, T.H., Momin, A., Park, H., Portz, B.J., Kelly, S., Wang, E., Sullards, M.C. and Wang, M.D. (2009) Sphingolipidomics: a valuable tool for understanding the roles of sphingolipids in biology and disease, J. Lipid Res., 50, S97-S102.

[137] Bielawski, J., Pierce, J.S., Snider, J., Rembiesa, B., Szulc, Z.M. and Bielawska, A. (2010) Sphingolipid analysis by high performance liquid chromatography-tandem mass spectrometry (HPLC-MS/MS), Adv. Exp. Med. Biol., 688, 46-59.

[138] Hannun, Y.A. and Obeid, L.M. (2011) Many Ceramides, J. Biol. Chem., 286, 27855-27862.

[139] Hannun, Y.A. and Obeid, L.M. (2008) Principles of bioactive lipid signalling: lessons from sphingolipids, Nat. Rev. Mol. Cell. Biol., 9, 139150.

[140] Gault, C.R., Obeid, L.M. and Hannun Y.A. (2010) An overview of sphingolipid metabolism: from synthesis to breakdown, Adv. Exp. Med. Biol., 688, $1-23$.

[141] Kolak, M., Westerbacka, J., Velagapudi, V.R., Wågsater, D., Yetukuri, L., Makkonen, J., Rissanen, A., Hakkinen, A.-M., Lindell, M., Bergholm, R., Hamsten, A., Eriksson, P., Fisher, R.M., Oresic, M. and Yki-Jarvinen, H. (2007) Adipose Tissue Inflammation and Increased Ceramide content characterize subjects with high liver fat content independent of obesity, Diabetes, 56, 1960-1968.

[142] Blachnio-Zabielska, A.U., Koutsari, Ch, Tchkonia, T. and Jensen M.D. (2012)

Sphingolipid content of human adipose tissue: relationship to adiponectin and insulin resistance, Obesity (Silver Spring), 20, 2341-2347.

[143] Yu, J., Xu, H., Mo, Z., Zhu, H. and Mao, X. (2009). Determination of myriocin in natural and cultured Cordyceps cicadae using 9fluorenylmethyl chloroformate derivatization and high-performance liquid chromatography with UVdetection, Anal. Sci., 25, 855-859.

Citation: Kuzmenko Dmitry Ivanovich, Klimentyeva Tatyana Konstantinovna. Ceramides with Different Acyl Chain Length in the Pathogenesis of Insulin Resistance. ARC Journal of Diabetes and Endocrinology.2018; 4(2):11-24. doi:dx.doi.org/10.20431/2455-5983.0402003.

Copyright: (C) 2018 Authors. This is an open-access article distributed under the terms of the Creative Commons Attribution License, which permits unrestricted use, distribution, and reproduction in any medium, provided the original author and source are credited. 